\title{
An Assessment of the evidence of Climate change in Bauchi, Nigeria
}

\section{*15YLVESTER, ODIANA; ABDULQUADIR, IBRAHIM ${ }^{2}$}

\author{
${ }^{1}$ Department of Environmental Management and Toxicology, Faculty of Life Sciences. University of Benin, P.M.B 1154, Benin City. \\ Nigeria \\ ${ }^{2}$ Department of Chemistry, Police Academy, Wudil, Kano Sttate, Nigeria \\ Correspondence e-mail: Odiana09@yahoo.com, Phone no. +2347030559493
}

\begin{abstract}
The study aimed at identifying the evidences of climate change in Bauchi. The emphasis was to find out if there are changes on the temperature and rainfall over time; to what extent these changes occur and likely impact these changes will have in Bauchi. The study was done in Bauchi town, Bauchi state of northeastern Nigeria. Elements of climate such as temperature and rainfall of the study area for a period of thirty (30) years between 1978 and 2008 were collected and analyzed using statistical method of Time Series Analysis. Findings from the study showed that rainfall in Bauchi was increasing by $0.2 \mathrm{~mm}$ per annum. The findings also showed that temperature was increasing by $0.0299^{\circ} \mathrm{c}$ per annum. This implies that Bauchi may be vulnerable to flooding and ecosystem change. And having a detrimental effect on agricultural produce thereby leading to food scarcity in the town. The annual increase in temperature by $0.0299^{\circ} \mathrm{c}$ and rainfall by $0.2 \mathrm{~mm}$ indicate that Climate Change is real in Bauchi $\odot$ JASEM
\end{abstract}

\section{http://dx.doi.org/10.4314/jasem/v19i3.5}

Keywords: climate change, Bauchi, food scarcity, Time Series Analysis, temperature and rainfall.

\section{INTRODUCTION}

Climate Change is the modification of the state of the climate that can be identified (example using statistical tests) by changes in the mean and or the variability of its properties, and that persists for an extended period typically decades or longer (IPCC, 2007). Climate Change is a normal part of earth's natural variability which is related to interractions among the atmosphere, ocean and land as well as changes in the amount of solar radiation reaching the earth (NOAA, 2007). In the past,Climate Change has led to extinction of many species, population, migration of plants and animals and pronounced changes in the land surface and ocean circulation. The speed of present Climate Change is faster than most of the past event making it more difficult for human societies and the natural world to adapt (NAS and The Royal Society, 2008). For instance, according to NOAA 2007 the last decade of the $20^{\text {th }}$ century and the beginning of the $21^{\text {st }}$ have been the warmest period in the entire global instrumental temperature record. Earth average surface air temperature has increased by about $0.8^{0} \mathrm{C}$ since 1900 , with much of the increase taking place since the mid 1970s (NAS and The Royal Society, 2008).

Climate Change is the result of human activities (IPCC, 2007). The activities include burning of fossil fuels and change in global pattern of land use (US EPA, 2015). These lead to emission of greenhouse gases majorly Carbon dioxide $\mathrm{CO}_{2}$ Methane $\mathrm{CH}_{4}$ and Nitrous Oxides $\mathrm{N}_{2} \mathrm{O}$. The combustion of fossil fuels account for anthropogenic $\mathrm{CO}_{2}$ emissions. Agriculture and clearing of forests are responsible for nearly $50 \%$ of human generated methane $\left(\mathrm{CH}_{4}\right)$ emissions and about $70 \%$ of anthropogenic nitrous oxide $\left(\mathrm{N}_{2} \mathrm{O}\right)$ emissions (Nwafor, 2006). Basically carbon dioxide $\left(\mathrm{CO}_{2}\right)$ contributes about $49 \%$, nitrous oxide $\left(\mathrm{N}_{2} \mathrm{O}\right)$ contributes about $6 \%$ and methane $\left(\mathrm{CH}_{4}\right)$ contributes about $18 \%$ to global warming (Karpagam, 2006). According to the United States National Academy of Sciences 2008, carbon dioxide increased by about $40 \%$ from 1800 to 2012 . The build up of greenhouse gases in the atmosphere alter its radiative balance. The net effect is to warm the Earth's surface and the lower atmosphere because greenhouse gases absorb some of the earth's outgoing heat radiation and reradiate it back towards the surface (UNFCCC, 2011).

Climate Change is now widely recognized as a major environmental problem facing the globe (UNEP, 2013). The risks associated with Climate Change are real but highly uncertain (Ogbo et al, 2013) It has the potential of affecting all natural and human system and may be a threat to human development and survival socially, politically and economically (Ali, 2011). WMO, 2008 stated that Climate Change will affect all countries, but people in the poorest countries and poor people in richer countries are 
more likely to suffer the most because they tend to live in high- risk areas such as unstable slopes and flood plains. Many of these persons depend on climate sensitive sectors such as agriculture. In 2012, Nigeria experinced the worst flood in over five decades which submerged and destroy farmlands of rice, yam, cassava, maize e.t.c in the neigbhouring states around rivers Niger and Benue as the rivers were filled to capacity by heavy rains (Ibekwe, 2012). The farmers in Bauchi are experiencing some changes in the yield and general characteristics of the crop they grow due to changes in rainfall and temperature, therefore affecting local food supply as well as the nation in general. This situation also affects the income of the farmers as well as the economy of the state and the country at large.

\section{MATERIALS AND METHODS}

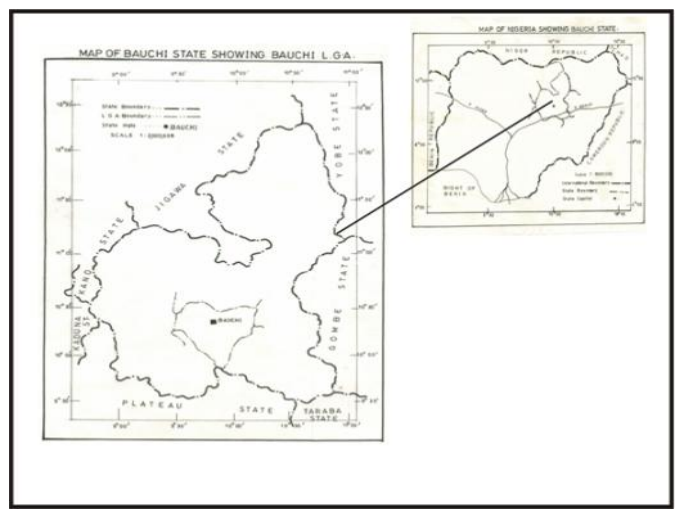

Map of Nigeria showing Bauchi state Source: Department of Surveying Federal Polythechnic Bauchi, 2009

The study was done in Bauchi town, Bauchi local Government area of Bauchi state Nigeria located at latitude $10^{\circ} 17^{\mathrm{I}} \mathrm{N}$ and longitude $09^{\circ} 49^{\mathrm{I}} \mathrm{E}$. with a population of 185550.68 (CENSUS DATA, 2006).

The area is drained by river system such as the River Gongola which originates in the Jos Plateau area. It transverses in a southwest - northeast direction through Dass, Tafawa - Balewa, Bogoro, Bauchi and Kirfi and thence to Gombe state. It has numerous tributaries such as Gubi etc. The river Gongola and its tributaries are of great importance to the area, for instance the impounding of Gubi to provide pipeborne water. Mean daily maximum temperature ranges from $27.0^{\circ} \mathrm{c}$ to $29.0^{\circ} \mathrm{c}$ between July and August and $37.6^{\circ} \mathrm{C}$ in March and April. The mean daily minimum ranges from $22.0^{\circ} \mathrm{C}$ in December and January to about $24.7^{\circ} \mathrm{C}$ in April and May (Wikipedia 2015).
Therefore, the effects of climate change directly have an impact on agriculture in Nigeria (Ladan, 2013).

Similarly, the residents of Bauchi are experiencing early dry up of their wells and other water sources and can still feel heat even during the peak of the harmattan period. A casual observer would have noticed the increasing frequency and sometimes intense, of unusual weather - linked phenomena in recent times (Okali 2004). Other effects of Climate Change include temperature rise, wild lives at risk of extinction, rise in sea level, increased risk of drought and floods, stronger storms and increased storm damage, change in the pattern and amount of rainfall, increase in heat related diseases, economic loss and change in landscape (Nature, 2015 and IPCC, 2007).

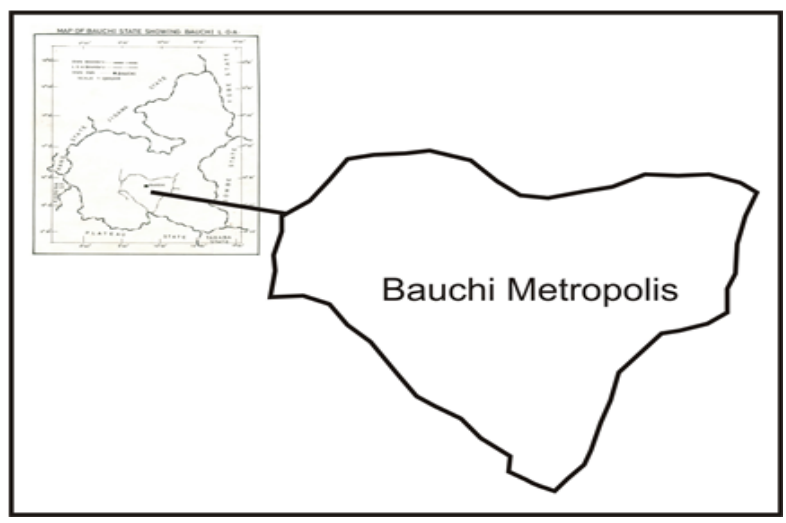

Map of Bauchi State showing Bauchi town Source: Department of Surveying Federal Polythechnic Bauchi, 2009

The sunshine hours ranges from about 5.1 hours in July to about 8.9 hours in November. October to February usually record the longest sunshine hours in Bauchi.

Humidity ranges from about $12 \%$ in February to about $68 \%$ in August.

The rainy season months are May to September, when humidity ranges from $37 \%$ to $68 \%$. Monthly rainfall ranges from $0.0 \mathrm{~mm}$ in December and January, to about $343 \mathrm{~mm}$ in July. Onset of rain is often in April while they end virtually by October (Wikipedia, 2008).

However the time of start and end of rainfall and its distribution has been affected by climate change.

The vegetation of Bauchi is Sudan Savanna type. The vegetation get richer and richer towards the southern part. The soil of Bauchi is a sandy loam type. Bauchi is an agricultural area by virtue of its vegetation type. 
Besides its vast fertile soil is an added advantage for growing crops such as maize, rice, millet, ground-nut, guinea corn etc.

Data Collection: The information for this retrospective study was obtained through analysis of rainfall and temperature data of Bauchi for a period of thirty (30) years between 1978 and 2008; through oral interview, personal observation and published reports/documents such as journals on climate change.

Oral interview: some selected persons of fifty (50) years and above were consulted for an in-depth interviewsn some recent events related to climate change such as early drying of wells; crop production and hotness of weather as compared to the past. The data collected was analyzed using Statistical Analysis

\section{RESULT AND DISCUSSION}

The annual temperature annual rainfall of Bauchi was obtained from Nigerian Meteorological Agency
Bauchi. Table 1 shows the mean annual temperature distribution of Bauchi between 1978 and 2008. Fig 1 shows the scatter of plot of the mean temperature of Bauchi. The plot reveals that the temperature in Bauchi is increasing. The equation of trend line fitted by the least square method as shown in Fig. 1 shows a positive slope of 0.0299 which indicate an increase in temperature with respect to time.

Table 2 shows the rainfall distribution of Bauchi of between 1978 and 2008. Fig. 2 shows the scatter plot of the rainfall in Bauchi. The plot reveals an increase in rainfall. The equation of trend line fitted by the least square method as shown in Fig: 2 shows a positive slope of 0.2 which indicate an increase in rainfall with respect to time. Therefore the amount of rainfall in Bauchi increases by $0.2 \mathrm{~mm}$ per annum.

The oral interview conducted among people of fifty (50) years and above indicated that well water which is the most reliable source of water in the town dries up more quickly in recent years than before

TABLE 1: Mean Annual Temperature Distribution Of Bauchi $\left({ }^{0} \mathrm{c}\right)$

\begin{tabular}{rl}
\hline YEARS & MEAN ANNUAL TEMPERATURE \\
& DISTRIBUTION OF BAUCHI $\left({ }^{\circ} \mathrm{C}\right)$ \\
\hline 1978 & 25.59 \\
1979 & 26.47 \\
1980 & 26.30 \\
1981 & 25.75 \\
1982 & 25.73 \\
1983 & 25.68 \\
1984 & 26.88 \\
1985 & 25.32 \\
1986 & 26.69 \\
1987 & 27.44 \\
1988 & 26.64 \\
1989 & 25.33 \\
1990 & 29.05 \\
1991 & 26.33 \\
1992 & 26.56 \\
1993 & 28.77 \\
1994 & 27.46 \\
1995 & 18.83 \\
1996 & 26.63 \\
1997 & 24.43 \\
1998 & 27.77 \\
1999 & 23.87 \\
2000 & 28.69 \\
2001 & 25.80 \\
2002 & 26.70 \\
2003 & 20.07 \\
2004 & 26.71 \\
2005 & 27.08 \\
2006 & 31.64 \\
2007 & 24.95 \\
2008 & 26.84 \\
\hline SOURCE: NIMET BAUCHI, 2009
\end{tabular}


Scatter of Temperatures

$$
\mathrm{Y}=25.9808+2.99 \mathrm{E}-02 \mathrm{X}
$$

$\mathrm{R}-\mathrm{Sq}=0.120$

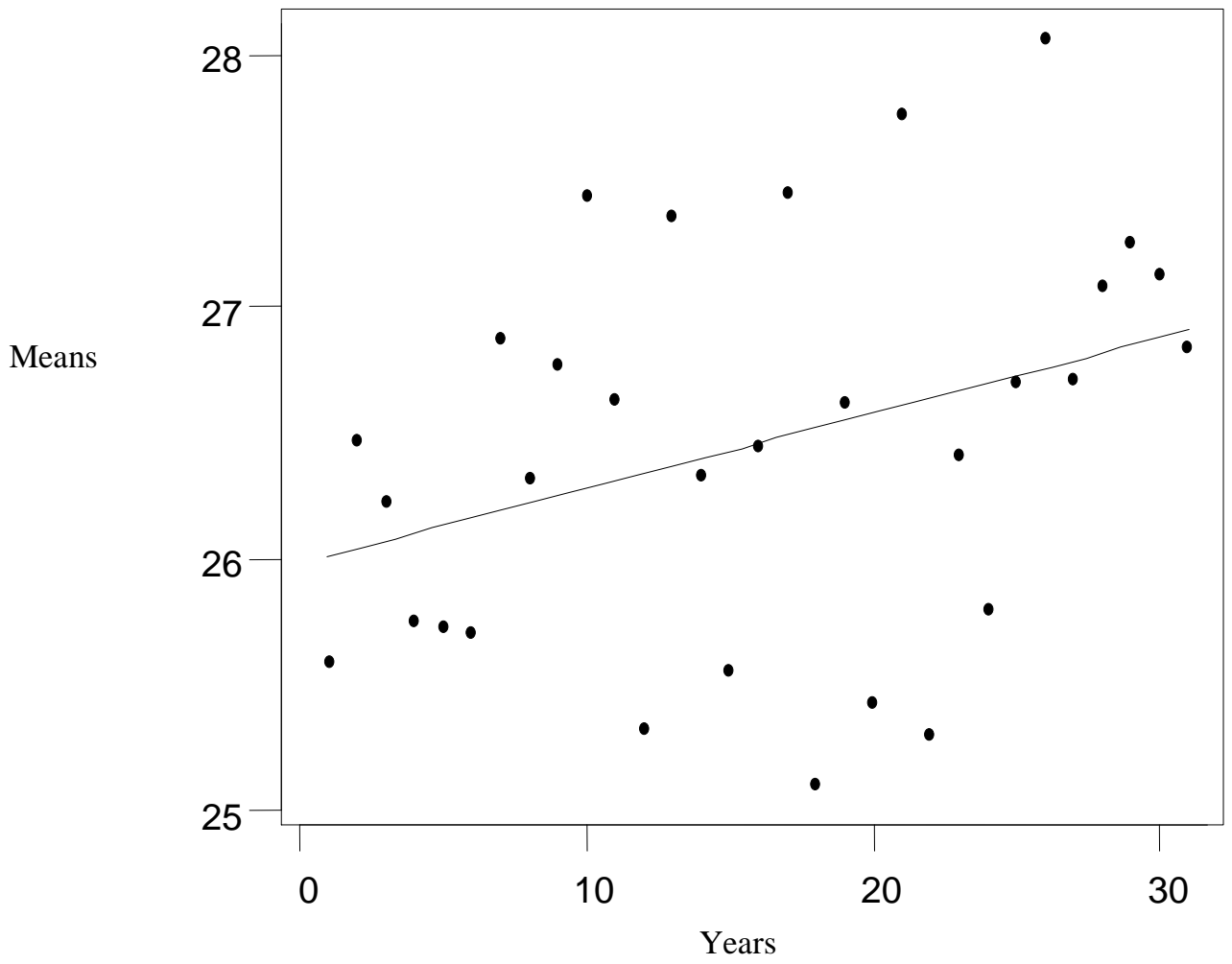

R-sq $=0.120$-allowable error.

From the graph above, the equation of trend line fitted by the least square method shows a positive slope of 0.0299 which indicates an increase of temperature with respect to time. Therefore the average mean temperature of Bauchi increases by $0.0299^{\circ} \mathrm{C}$ per annum

Fig 1: Scatter plot of temperature

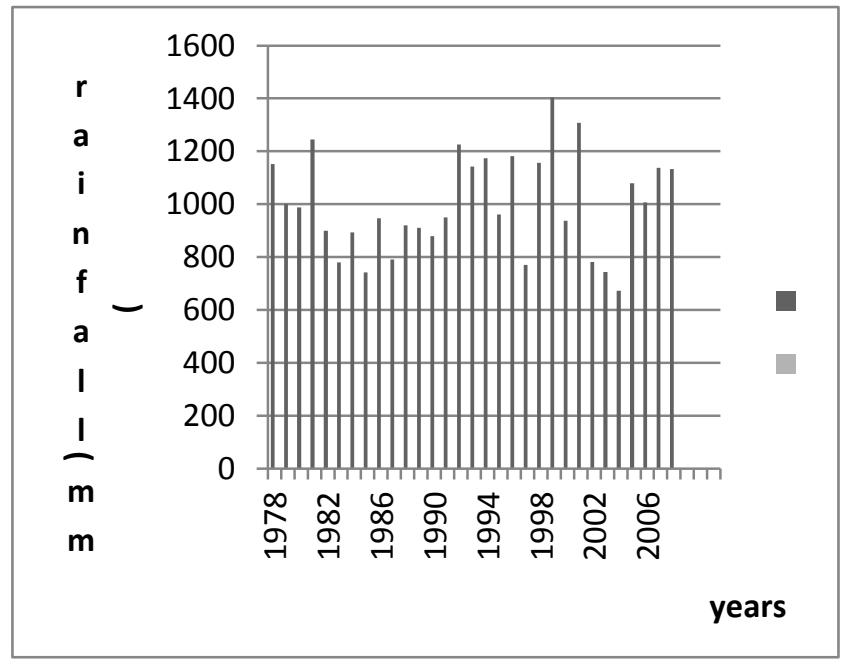

Annual Rainfall Distribution of Bauchi

*I SYLVESTER, ODIANA; ABDULQUADIR, IBRAHIM ${ }^{2}$ 
Table 2: Annual Rainfall Distribution Of Bauchi

\begin{tabular}{ll}
\hline YEARS & ANNUAL RAINFALL \\
& DISTRIBUTION OF BAUCHI $(\mathrm{mm})$ \\
\hline 1978 & 1151.00 \\
1979 & 1000.30 \\
1980 & 988.20 \\
1981 & 1244.80 \\
1982 & 900.00 \\
1983 & 779.00 \\
1984 & 893.70 \\
1985 & 742.20 \\
1986 & 946.20 \\
1987 & 790.90 \\
1988 & 920.70 \\
1989 & 909.70 \\
1990 & 879.60 \\
1991 & 949.60 \\
1992 & 1226.00 \\
1993 & 1141.90 \\
1994 & 1174.30 \\
1995 & 961.40 \\
1996 & 1180.80 \\
1997 & 770.00 \\
1998 & 1156.50 \\
1999 & 1403.80 \\
2000 & 937.00 \\
2001 & 1307.2 \\
2002 & 781.00 \\
2003 & 744.00 \\
2004 & 672.10 \\
2005 & 1078.50 \\
2006 & 1007.20 \\
2007 & 1136.90 \\
2008 & 1133.10 \\
\hline
\end{tabular}

Scatter plot of rainfall

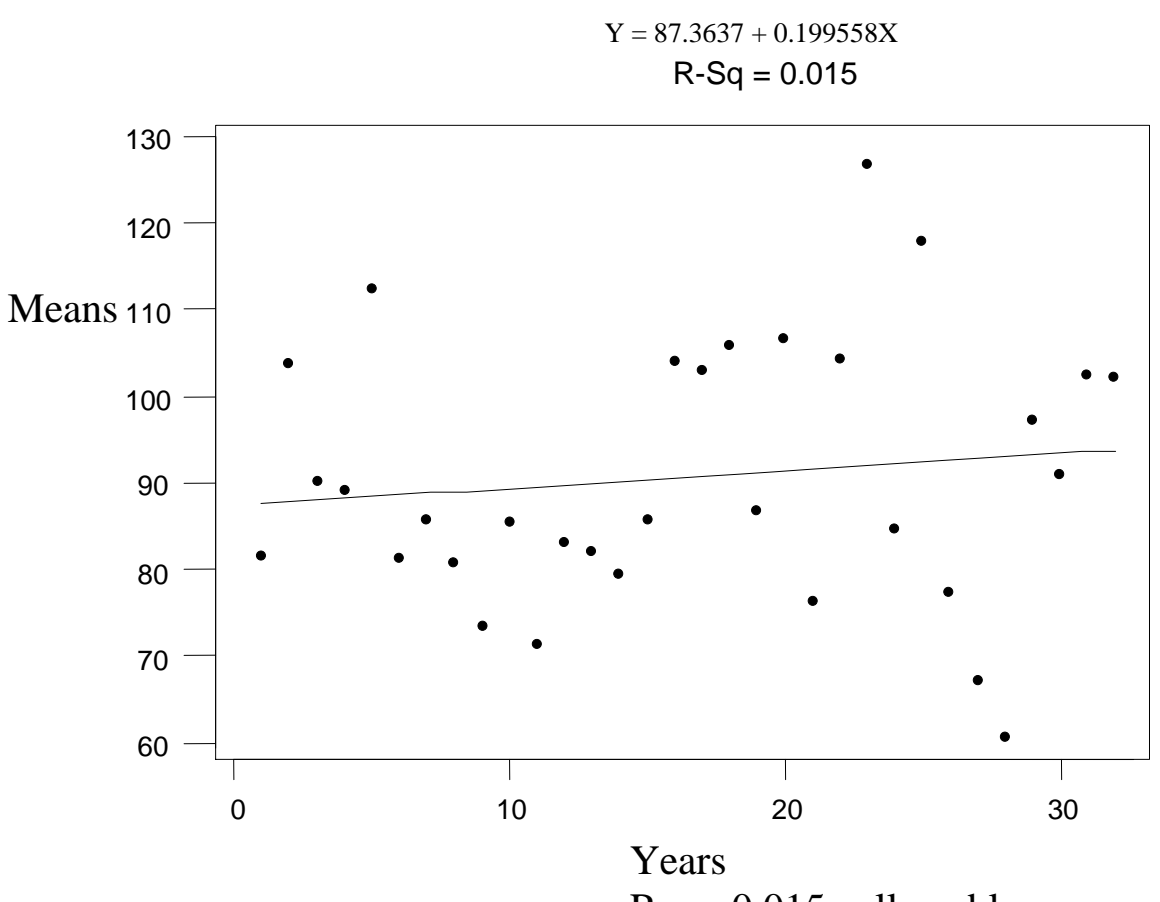

$\mathrm{R}$-sq $=0.015$-allowable error

*I SYLVESTER, ODIANA; ABDULQUADIR, IBRAHIM ${ }^{2}$ 
From the graph above, the equation of trend line fitted by the least square method shows a positive slope of 0.2 which indicates an increase of rainfall with respect to time. Therefore the amount of rainfall in Bauchi increases by $0.2 \mathrm{~mm}$; Fig 2: Scatter plot of rainfall

The average mean temperature of Bauchi increases by $0.0299^{\circ} \mathrm{c}$ per annum. National Academy of Science and The Royal Society (2008) stated that Earth average surface air temperature has increased by about $0.8^{\mathrm{c}} \mathrm{c}$ since 1900 , with much of the increase taking place since the mid 1970s. The warming as from 2005 to the next twenty (20) years is projected to be about $0.2^{0} \mathrm{c}$ per decade (IPCC, 2007). The mean annual temperature of Bauchi is $28.5^{\circ} \mathrm{c}$ (Wikipedia, 2015). The effects of Climate Change are already affecting livelihood and will have greater effects in the future. For instance, Gerad, S. 1988 and Sowunmi et al, (2010) said that maize requires temperature of between $21^{\circ} \mathrm{c}$ and $30^{\circ} \mathrm{c}$ for optimum production. If the current trend continues, the production of maize in Bauchi will greatly reduce if not impossible. In Bauchi, maize is one of the most important cereal for both human and animal consumption (FAO, 2013). Its sustainable production promote job opportunities and increased family incomes (Tekwa et al 2011). Researchers estimated that rising global temperature in the past century has led to about $5 \%$ increase of atmospheric water vapour over the oceans (EPA and IPCC, 2007).Because precipitation is generated mainly by weather systems that feed on the water vapour stored in the atmosphere, this has generally increased the intensity of precipitation or the risk of heavy rain etc. As climate continues to warm, atmospheric concentration of water vapour are predicted to continue to rise, leading to an increase in average amount of precipitation. Higher temperatures also increase evaporation, accelerating the drying of land surface and leading to droughts and floods depending on regions (EPA and IPCC, 2007). Thereby increasing the risk of flooding in Bauchi.

.The drying up of well as observed by persons interviewed is partly related to the high rate of evaporation that occurs in recent times due to increase in temperature as supported by EPA and IPCC 2007.

Similar oral interview conducted on some selected people in the town as well as some observation made indicated that in recent years, the harmattan period which is a dry, dusty and cold weather is not as it used to be some ten (10) or fifteen (15) years ago due to increase in temperature. Hence, most people in the town still put on their air-conditioners, refrigerators and fans in offices and at homes as if they were in hot periods.

Conclusion: The study shows that temperature in Bauchi is increasing by $0.0299^{\circ} \mathrm{c}$ per annum. This increase is affecting livelihood and will have greater effect in the future. For instance, maize which is one of the commonest source of food in Bauchi will be affected as condition for its production will soon be unfavourable. Its optimum production requires a temperature of between $21^{\circ} \mathrm{c}-30^{\circ} \mathrm{c}$. The mean annual temperature of Bauchi is $28.5^{\circ} \mathrm{c}$. Therefore, with annual increase of $0.0299^{\circ} \mathrm{c}$, the maximum temperature require for maize production will soon be reached. This is a concern food production and sustainability .

The study also shows that rainfall in Bauchi is increasing by $0.2 \mathrm{~mm}$ annually. Therefore, with the increase observed there is a high risk of flooding and ecosystem change.

The annual increase in temperature by $0.0299^{\circ} \mathrm{c}$ and rainfall by $0.2 \mathrm{~mm}$ indicate that Climate Change is real in Bauchi

Acknoledgement: I give thanks to God Almighty for health, strength and other provisions. I equally appreciate the support from staff of the Departments of Environmental Management and Toxicology, University of Benin, Environmental Management Technology Abubakar Tafawa Balewa University Bauchi, NIMET Bauchi and other people who added to the success of this work such as financial and moral supports.

\section{REFERENCES}

Ali, Y O (2011). Legal profession and climate change in NigeriaAccessed 29 December 2014 Available: http://www.yusufali.net

FAO (2013). Analysis of Incentives and Disincentive for Maize in Nigeria. Accessed 16 January, 2015 Available: www.fao.org

Gerad,S (1988). "Tropical Agriculture”. Macmillan: Ibadan Pp75-83.

Ibekwe N (2012). Floods: Sad tales from affected states. Accessed 29 December 2014 Available: http// www.premiumtimes.com

IPCC (2007). Fourth Assessment Report. Working Group 1: The Physical Science. Accessed Available: http://www.ipcc.gov 
Karpagam,M (2006)."Environmental Economics". Sterling Publishers: New Delhi Pp 278-283.

Ladan, S I (2014). Appraisal of climate change and agriculture in Nigeria. Accessed 29 December 2014 Available: http:// www.academicjournals.org

National Oceanic and Atmospheric Administration (2007). Climate Change. Accessed 22 January 2015 Available: http:// www.nws.noaa.gov

National Academy of Science and The Royal Society (2008) Climate Change Evidences and Causes. Accessed 30 January 2015 Available: http:// dels.nas.edu

Nwafor,J C (2006)“Environmental Impact Assessment For Sustainable Development." El’Demak Publishers: Enugu. Pp359-383.

Ogbo A, Ndubisi E. L. and Ukpere W (2013) Risk Management Challenges of Climate Change in Nigeria.krepublishers 41(3):221-235. Available:http://www.krepublishers.com

Okali, D (2004). "Climate Change and Nigeria: A Guide for Policy makers. Accessed1 December 2008 Available: http://www.nestinterative.com

Journal of Environmental \& Earth science 2(1): 1930. Available:http://www.maxwellscience.com $16 / 1 / 15$
Tekwa I.J and Bwade E.K (2011). Estimation of Irrigation Water Requirement of Maize (zea.mays) using pan evaporation method in Maiduguri North Eastern Nigeria 2011; 13(1):42-48Accessed 16 January 2015. Available: http;// www.cigrjournal.org

UNEP (2013). Climate change-home. (2013). www.unep.org/climatechange

UNFCCC (2011). The status of Climate Change Science Today. Acccessed 30 January 2015 Available:http://unfccc.int

United States EPA (2013) Climate Change Impact on Agriculture and Food Supply

Available:http://www.epa.gov

United States EPA .Climate Change. (2007).Accessed 8 December 2008

Available:http://www.epa.gov

Wikipedia (2015). Climate of Bauchi. Accessed 15 February 2015 Available:http:// www.wikipedia.org

World Meteorological Organisation (2008). Climate Change and Disaster Risk Reduction Accessed 30 January 2015 Available:http://www.wmo.int $30 / 1 / 15$ 